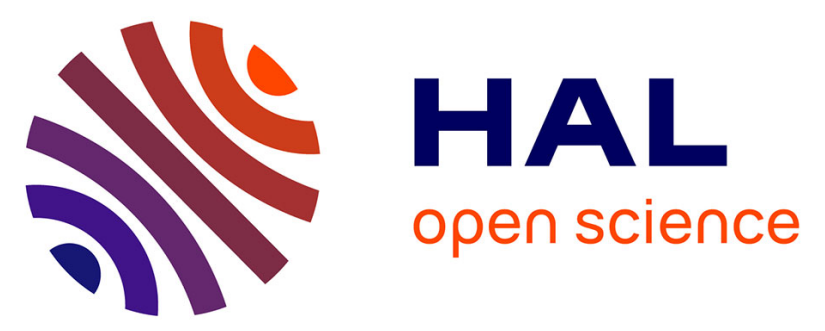

\title{
Cryptic genomic imbalances in de novo and inherited apparently balanced chromosomal rearrangements: array CGH study of 47 unrelated cases.
}

Caroline Schluth-Bolard, Bruno Delobel, Damien Sanlaville, Odile Boute, Jean-Marie Cuisset, Sylvie Sukno, Audrey Labalme, Bénédicte Duban-Bedu, Ghislaine Plessis, Sylvie Jaillard, et al.

\section{To cite this version:}

Caroline Schluth-Bolard, Bruno Delobel, Damien Sanlaville, Odile Boute, Jean-Marie Cuisset, et al.. Cryptic genomic imbalances in de novo and inherited apparently balanced chromosomal rearrangements: array CGH study of 47 unrelated cases.. European Journal of Medical Genetics, 2009, 52 (5), pp.291-6. 10.1016/j.ejmg.2009.05.011 . inserm-00405484

\section{HAL Id: inserm-00405484 https://www.hal.inserm.fr/inserm-00405484}

Submitted on 25 Aug 2009

HAL is a multi-disciplinary open access archive for the deposit and dissemination of scientific research documents, whether they are published or not. The documents may come from teaching and research institutions in France or abroad, or from public or private research centers.
L'archive ouverte pluridisciplinaire HAL, est destinée au dépôt et à la diffusion de documents scientifiques de niveau recherche, publiés ou non, émanant des établissements d'enseignement et de recherche français ou étrangers, des laboratoires publics ou privés. 


\section{Cryptic genomic imbalances in de novo and inherited apparently balanced chromosomal rearrangements: array CGH study of 47 unrelated cases.}

Caroline Schluth-Bolard ${ }^{\mathrm{a}, \mathrm{b}}$, Bruno Delobel ${ }^{\mathrm{c}}$, Damien Sanlaville ${ }^{\mathrm{a}, \mathrm{b}}$, Odile Boute ${ }^{\mathrm{d}}$, Jean-Marie Cuisset $^{\mathrm{e}}$, Sylvie Sukno ${ }^{\mathrm{f}}$, Audrey Labalme ${ }^{\mathrm{a}}$, Bénédicte Duban-Bedu ${ }^{\mathrm{c}}$, Ghislaine Plessis ${ }^{\mathrm{g}}$, Sylvie Jaillard ${ }^{\mathrm{h}, \mathrm{i}}$, Christèle Dubourg ${ }^{\mathrm{i}, \mathrm{j}}$, Catherine Henri ${ }^{\mathrm{h}}$, Josette Lucas ${ }^{\mathrm{h}}$, Sylvie Odent ${ }^{\mathrm{i}, \mathrm{k}}$, Laurent Pasquier $^{\mathrm{i}, \mathrm{k}}$, Henri Copin ${ }^{1}$, Philippe Latour ${ }^{\mathrm{m}}$, Marie-Pierre Cordier ${ }^{\mathrm{n}}$, Gwenaël Nadeau ${ }^{\mathrm{o}}$, Marianne Till ${ }^{\mathrm{a}}$, Patrick Edery ${ }^{\mathrm{a}, \mathrm{b}}$ and Joris Andrieux ${ }^{\mathrm{p}, *}$.

a: Hospices Civils de Lyon, Service de Cytogénétique Constitutionnelle, Lyon, France

b: Université Claude Bernard Lyon 1, Faculté de Médecine Lyon Nord, Lyon, France

c: GHICL, Hôpital St-Vincent de Paul, Centre de Génétique Chromosomique, Lille, France

d: CHRU Lille, Hôpital Jeanne de Flandre, Service de Génétique Clinique, Lille, France

e: CHRU Lille, Service de Neuropédiatrie, Lille, France

f: GHICL, Hôpital St-Vincent de Paul, Service de Neuropédiatrie, Lille, France

g: CHU Clémenceau, Service de Génétique, Caen, France

h: CHU Pontchaillou, Laboratoire de Cytogénétique et Biologie Cellulaire, Rennes, France

i: Faculté de Médecine, UMR 6061, IFR 140 GFAS, Rennes France

j: CHU Pontchaillou, Laboratoire de Génétique Moléculaire, Rennes, France

k: CHU Hôpital Sud, Service de Génétique Médicale, Rennes, France

1: CHU d'Amiens, Unité de Cytogénétique, Amiens, France

m: Hospices Civils de Lyon, CBPE, Laboratoire de Neurogénétique, Lyon, France

n: Hospices Civils de Lyon, HFME, Service de Génétique, France

o: CH Valence, Service de Cytogénétique, Valence, France

p: CHRU Lille, Hôpital Jeanne de Flandre, Laboratoire de Génétique Médicale, Lille, France

Corresponding author; Tel : 33 (0)3 204461 21, Fax : 33 (0)3 20446804

Email : j-andrieux@chru-lille.fr 


\begin{abstract}
Investigations of apparently balanced chromosomal rearrangements in patients with abnormal phenotype by molecular cytogenetics tools, especially by array $\mathrm{CGH}$, revealed a proportion of unsuspected imbalances. It was estimated recently that $40 \%$ of apparently balanced de novo translocations with abnormal phenotype were associated with cryptic deletion.
\end{abstract}

We explored 47 unrelated mental retardation patients carrying an apparently balanced chromosomal rearrangement with high-resolution oligonucleotides arrays. We included 33 de novo cases (21 translocations, 7 inversions and 5 complex chromosomal rearrangements (CCR)) and 14 inherited cases (7 translocations, 5 inversions and 2 CCR).

Twenty of the 47 cases $(42.6 \%)$ carried a cryptic deletion ranging from $60 \mathrm{~kb}$ to 15.37 $\mathrm{Mb}$. It concerned 16/33 de novo rearrangements (8/21 translocations, 4/7 inversions and 4/5 CCR) and 4/14 inherited rearrangements (1/7 translocations, 2/5 inversions and 1/2 CCR). The proportion of imbalances was not statistically different between de novo and inherited cases.

Our results support that about $40 \%$ apparently balanced chromosomal rearrangements with abnormal phenotype are in fact imbalanced and that these rearrangements should be systematically investigated by array CGH independently of their de novo or inherited character.

Keywords: array CGH, apparently balanced translocations, abnormal phenotype 


\section{Introduction}

It is estimated that standard karyotype displayed chromosome aberrations in 3 to $15 \%$ of patients affected with mental retardation $[24,29,30]$. Most of them are unbalanced by either numerical (trisomy, monosomy) or structural (deletion, duplication...) anomalies. However, apparently balanced structural rearrangements are present in $0.6 \%$ of mentally retarded patients [24]. About $6 \%$ of de novo apparently balanced translocations [32] and $23 \%$ of apparently balanced complex chromosomal rearrangements (CCR) defined by three or more breakpoints [21] are associated with an abnormal phenotype. These balanced rearrangements were demonstrated to be responsible for the phenotype by different mechanisms such as gene disruption at the breakpoints $[13,14]$, position effect $[8,16,17]$ or disturbance of parental imprinting [6]. Development of Fluorescent In Situ Hybridization (FISH) or Comparative Genomic Hybridization (CGH) on chromosomes showed that a proportion of these rearrangements was in fact associated with cryptic imbalances $[1,3,12,15,18,23]$. More recently, array CGH technology [28] has been used to investigate apparently balanced translocations associated with an abnormal phenotype and has found cryptic deletion in about 30 to $50 \%$ of them $[2,4,10]$.

Here, we explored 47 patients presenting with mental retardation and carrying an apparently balanced chromosomal rearrangement with high-resolution oligonucleotide array in order to detect cryptic imbalances accounting for the phenotype. These rearrangements were either de novo (33 patients) or inherited (14 patients) and included reciprocal translocations, peri- and paracentric inversions or CCR. We estimated their frequency and defined the place of this technology in a diagnostic setting. 


\section{Material and methods}

\subsection{Patients}

Forty-seven patients (26 males and 21 females) with mental retardation and/or multiple congenital malformations have been included in the study after fully informed consent was obtained. All patients had been assessed by a clinical geneticist. Phenotype range was very wide and included variable degree of mental retardation with or without malformations and facial dysmorphism. For all of them, standard karyotype (RHG, 500 bands) showed an apparently balanced rearrangement including 28 reciprocal translocations, 12 inversions and 7 CCR. Thirty-three balanced rearrangements occurred de novo (21 translocations, 7 inversions and $5 \mathrm{CCR}$ ) and 14 were inherited from a healthy parent (7 translocations, 5 inversions and 2 CCR) (Table 1). There was no other evident cause for their phenotype. Patients' karyotypes are summed up in Table 1. Parents' blood sample was required to assess if the imbalances detected by array CGH were de novo or inherited.

\subsection{Array $\mathrm{CGH}$}

Agilent ${ }^{\circledR}$ oligonucleotide arrays were used according to the manufacturer instruction (Agilent Human Genome CGH Microarray kit $244 \mathrm{~A}{ }^{\circledR}$ and $44 \mathrm{~K} \AA$ ). The overall median probe spacing was $43 \mathrm{~kb}$ for $44 \mathrm{~K}$ array and $8.9 \mathrm{~kb}$ for $244 \mathrm{~A}$ array. Thirty eight patients DNA were analyzed with a 44,000 oligonucleotides array and 9 patients DNA with a 244,000

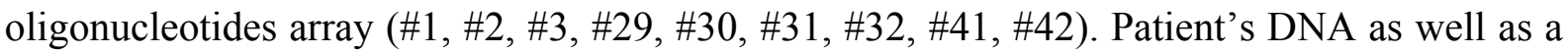
reference DNA were digested with RsaI and AluI. Each digested DNA product was labelled by random priming using either Cy5-dUTP or Cy3-dUTP. After columns-purification, probes were denaturated and pre-annealed with $50 \mu \mathrm{g}$ of human Cot-1 DNA (Invitrogen ${ }^{\circledR}$, California). Hybridization was performed at $65^{\circ} \mathrm{C}$ during 40 hours. After washing, the array was scanned and analyzed with Feature Extraction ${ }^{\circledR} 9.1$ software. Control DNA consisted 
either of a sex-matched pool of genomic DNA commercially available (Promega ${ }^{\circledR}$, USA) or of two other patients DNA, according to the loop model [22]. Results were interpreted with CGH analytics ${ }^{\circledR} 4.5$ software by two investigators. A copy number variation was considered if at least 3 contiguous oligonucleotides presented an abnormal $\log$ ratio $(>+0,66$ or $<-0,75)$. Results were compared to data recorded in the database of genomic variants.

\subsection{Fluorescent in situ hybridization (FISH)}

FISH analyses on patient metaphases were performed in order to confirm the results of array CGH. Each time a microdeletion was confirmed, FISH was performed on parents' sample in order to check if the genomic imbalance was de novo or inherited. BACs were chosen on UCSC and Ensembl databases. FISH using BAC clones was performed as described by Romana et al [24]. DNA was fluoresceine or rhodamine labeled by nicktranslation. Probes were coprecipitated with human Cot-1 DNA (Invitrogen ${ }^{\circledR}$, California) and then resuspended in hybridization buffer (50\% formamide). After denaturation, overnight hybridization and post-hybridization wash, slides were DAPI counterstained and were read using a fluorescent microscope equipped with a CCD camera. All details about BAC clones used are available on request.

\subsection{Quantitative PCR (qPCR)}

When FISH was not possible, the confirmation of allelic imbalance in the target chromosome region was analyzed using SYBR Green I based quantitative real time PCR with LightCycler ${ }^{\circledR}$ (Roche Diagnostics, GmbH, Mannheim, Germany). The protocol involved amplification of a target gene and a reference gene (ADORA2B, HGNC:264) (primers sequences available on request). Quantitative PCR protocol was conducted in triplicate in a 20 $\mu \mathrm{L}$ final volume containing $10 \mu \mathrm{L}$ of SYBR PCR Master Mix (2X) (Qiagen ${ }^{\circledR}, \mathrm{GmbH}$, Hilden, 
Germany), $1.5 \mu \mathrm{M}$ of each primer and $10 \mathrm{ng}$ of genomic DNA. The thermal cycling conditions comprised a 15 min polymerase activation at $95^{\circ} \mathrm{C}$ followed by 35 cycles of $15 \mathrm{~s}$ at $95^{\circ} \mathrm{C}, 30 \mathrm{~s}$ at $60^{\circ} \mathrm{C}$ and $15 \mathrm{~s}$ at $72^{\circ} \mathrm{C}$. Experiments need to have a coefficient of variation for triplicate samples inferior to 0.1 . PCR efficiency is calculated as followed: $10^{-1 / \text { slope }}$. Efficiency of qPCR is equal to $100 \%$ when $10^{-1 / \text { slope }}=2$ meaning that quantity of DNA is multiplied by 2 at each cycle of the PCR. We consider that PCR efficiency do be superior to $98 \%$ to assure good results.

A melting curve step was used to examine each sample for purity and specificity and the size of the amplicons was checked by electrophoresis. The calculation is based on the $\mathrm{Ct}$ values (minimal number of PCR cycles necessary to detect a fluorescence issued by the SYBR Green I) obtained by the Light Cycler software. A series of 5-fold dilutions of human genomic DNA corresponding to 0.5 to $8 \mathrm{ng} / \mu \mathrm{L}$ was included in each experiments in order to generate an external standard curve $(\mathrm{Ct}=\mathrm{A} \times \log [$ Concentration DNA] $+\mathrm{B})$ that allowed to estimate DNA concentration for each sample. Relative copy number is then calculated as the [target gene]/[reference gene] ratio.

\section{Results}

Overall, array CGH demonstrated cryptic imbalances in 20 of the 47 patients $(42.6 \%)$. It consisted of 21 deletions ranging from $60 \mathrm{~kb}$ to $15.37 \mathrm{Mb}$. Nine of the 21 imbalances were located in regions not involved in the balanced rearrangement. Two of these cryptic imbalances were inherited from a healthy parent. The proportion of imbalances detected in de novo $(16 / 33,48.5 \%)$ and in inherited rearrangements $(4 / 14,28.6 \%)$ was not statistically different $(\mathrm{p}<0.34)$. Results and phenotypes of these patients are described in detail in Table 2 .

\section{De novo rearrangements}


Microdeletions were detected in 16 of the 33 de novo structural rearrangements (48.5\%). They ranged from $60 \mathrm{~kb}$ to $15.37 \mathrm{Mb}$ and were all de novo. Nine of them were at distance from initial breakpoints. One patient (\#42) presented two deletions.

Reciprocal translocations: $38.1 \%(8 / 21)$ of apparently balanced translocations showed an associated deletion ranging from $60 \mathrm{~kb}$ to $15.37 \mathrm{Mb}$. Three of them were located at distance from translocation breakpoints (\#1, \#22, \#27).

Inversions: Four of the seven $(57.1 \%)$ de novo inversions were imbalanced. Microdeletions ranged from 1.06 $\mathrm{Mb}$ to $8.87 \mathrm{Mb}$. Three of them were located on a different chromosome than the chromosome carrying the inversion (\#29, \#34, \#36).

Complex chromosomal rearrangements: Four of the five de novo CCR were imbalanced (80 \%) with deletions ranging from $690 \mathrm{~kb}$ to $4.9 \mathrm{Mb}$. Case \#42 showed two deletions, one on a chromosome 2 at distance from the breakpoint and one on a chromosome 6 at the breakpoint.

\section{$\underline{\text { Inherited rearrangements }}$}

Cryptic rearrangements were detected in 4 of the 14 inherited structural rearrangements $(28.6 \%)$. These were only deletions ranging from $80 \mathrm{~kb}$ to $3.64 \mathrm{Mb}$. Two of them were inherited from a healthy parent (\#9, \#31). Two of them were at distance from initial breakpoints $(\# 9, \# 31)$.

Reciprocal translocations: One of the seven (14.3\%) apparently balanced translocations showed a $1.21 \mathrm{Mb}$ deletion at distance from the breakpoints (\#9). It was inherited from the healthy father who also carries the balanced translocation.

Inversions: Two of the five (40\%) inversions were imbalanced. Deletion size was respectively of $80 \mathrm{~kb}$ and $1.23 \mathrm{Mb}$. One of these imbalances was located on a different 
chromosome than the chromosome carrying the inversion and was inherited from the father who also transmitted the inversion (\#31).

Complex chromosomal rearrangements: One of the two CCR (50\%) presented a 3.64 $\mathrm{Mb}$ de novo deletion.

\section{$\underline{\text { Results according to the array resolution }}$}

Thirty-eight cases were studied with $44 \mathrm{~K}$ array. It displayed 15 microdeletions ranging from $300 \mathrm{~kb}$ to $15.37 \mathrm{Mb}($ mean $=4.24 \mathrm{Mb})$. Nine cases were investigated with a $244 \mathrm{~K}$ array (\#1, \#2, \#3, \#29, \#30,\#31, \#32, \#41, \#42). Six microdeletions in five patients were found ranging from $60 \mathrm{~kb}$ to $8.87 \mathrm{Mb}$ (mean: $3.16 \mathrm{Mb}$ ). In two cases (\#1, \#31) in whom the deletion was of small size (less than $100 \mathrm{~kb}$ ), it could not be concluded if the deletion accounted for the phenotype really.

\section{Discussion}

Development of more and more accurate molecular cytogenetics techniques such as FISH, CGH on chromosomes and array CGH allowed to dissect apparently balanced chromosomal rearrangements in patients with abnormal phenotype. These techniques displayed the complexity of reciprocal translocations that could in fact involve up to 5 chromosomes in a combination of translocations, insertions and inversions $[1,3,10,23]$. They also showed presence of cryptic imbalances either at the chromosomal breakpoint or at distance $[1,3,10,12,15,18,23]$. Characterization by FISH of 40 apparently balanced chromosomal rearrangements from the Developmental Genome Anatomy Project revealed imbalances in $37 \%$ of them (15/40 cases) [12]. Array CGH is the most recent technology used to characterize this type of rearrangements and has the advantage over FISH approach to investigate the entire genome and not only breakpoint regions. 


\section{Cryptic imbalances in apparently balanced de novo rearrangements}

Beside several isolated case reports [5,11], larger studies using array CGH estimated the proportion of imbalances in apparently balanced de novo translocations (Table 3) $[2,4,10]$. Gribble et al. studied 10 patients using a BAC/PAC array and found 5/10 imbalances from 1.2 to $6.2 \mathrm{Mb}$ [10]. De Gregori et al investigated 59 patients including de novo reciprocal translocations and CCR. They showed i) that $40 \%$ of apparently balanced translocations with abnormal phenotype are associated with a cryptic deletion, ii) that $18 \%$ of them are in fact more complex and iii) that almost all CCR with abnormal phenotype are imbalanced [4]. More recently, Baptista et al found four imbalances in 14 patients (28.6\%) [2]. In the present study, we found cryptic deletion in $48.5 \%$ of cases (16/33) of apparently balanced de novo rearrangements associated with an abnormal phenotype including 8 translocations, 4 inversions and $4 \mathrm{CCR}$. Twenty-seven percent of them revealed more complex as initially thought. In 15 of these cases, the phenotype could be related to the cryptic imbalance according to its de novo nature, its size and its gene content [19]. For example, case \#43 showed a de novo $690 \mathrm{~kb}$ deletion involving the TWIST gene that accounted for his SaethreChotzen phenotype and was described elsewhere [26]. These results are consistent with the previous studies leading us to conclude that about $40 \%$ of apparently balanced de novo rearrangements with abnormal phenotype are associated with a cryptic imbalance. The yield of array $\mathrm{CGH}$ in MCA/MR patients with normal standard karyotype is about 10 to $17 \%$ $[20,27]$. So it seems that genomic imbalances are more likely to be found in MCA/MR patients with structural chromosome rearrangements than in patients without. Interestingly, no case of our cohort had copy-number gains, which is also consistent with the previous studies $[2,4,10]$. This could be the fact of a particular mechanism generating preferentially loss of material. But gains of material could also be associated with milder phenotype or a different phenotype than MCA/MR and may not have been recruited. Finally, microdeletions unrelated 
to the breakpoints involve about $20 \%$ of cases [4]. However, their significance is still unclear. They may either be part of a complex rearrangement involving multiple breakpoints and fusions at different part of the genome or be associated to the balanced rearrangement fortuitously.

\section{Cryptic imbalances in apparently balanced inherited rearrangements}

Four out of 14 inherited cases of chromosomal rearrangements were imbalanced: one translocation, 2 inversions and $1 \mathrm{CCR}$ (cases \#9, \#31, \#40 and \#45). In two cases the cryptic imbalance occurred de novo and could be causally related to the phenotype of the patients. In two other cases (\#9 and \#31) the cryptic imbalance was inherited from the healthy parent who also transmitted the balanced rearrangement. So it cannot be concluded if these deletions were new benign variations not reported in databases yet or if they contributed to the phenotype in a complex manner like variable expression, unmasking of recessive mutation on the other allele, disturbance of parental imprinting or combination of multiple genetic defects. So, we believe that array $\mathrm{CGH}$ is also useful to explore patients with an abnormal phenotype carrying an inherited chromosomal rearrangement.

\section{Diagnostic yield according to array resolution}

Diagnostic yield of $244 \mathrm{~K}$ arrays was not statistically different from $44 \mathrm{~K}$ arrays in the present study. Although $244 \mathrm{~K}$ array identified deletions less than $100 \mathrm{~kb}$ in two cases (cases $\# 1$ and \#31), it was not possible to conclude about their pathological significance. Indeed, these deletions included a single gene, neither referenced in databases of genomic variants nor morbid databases (OMIM). Investigations to confirm the role of these genes in the phenotype of patients are time-consuming and go beyond the means of a diagnostic laboratory. The smallest deletion detected by $44 \mathrm{~K}$ was $300 \mathrm{~kb}$ in this series (case \#22). Moreover, it has 
already been demonstrated that $44 \mathrm{~K}$ array detected as much as pathological imbalances than $244 \mathrm{~K}$ array but detected less copy number polymorphisms [7]. So, the use of $44 \mathrm{~K}$ arrays seems compatible in a high-throughput diagnostic setting since it provides a good diagnostic yield and avoids too many false positive cases and time-consuming verifications.

\section{Conclusion}

In conclusion, we studied 47 cases of MCA/MR patients presenting an apparently balanced chromosomal rearrangement either de novo or inherited by array CGH. Genomic imbalances were identified in $48.5 \%$ of de novo cases and $28.6 \%$ of inherited cases. These results support previous studies showing that $40 \%$ of patients with MCA/MR and an apparently balanced translocation carry a cryptic imbalance that can account for the phenotype. We suggest that the management of MCA/MR patients with an apparently balanced chromosome rearrangement should include a systematic investigation by array $\mathrm{CGH}$, whatever the type of rearrangements (translocation, inversion or CCR) and whatever the inheritance (de novo or familial). If array CGH fails to detect any imbalance, breakpoints should be investigated to look for position effect $[8,16,17]$ or gene disruption $[13,14]$ that occurs in $35 \%$ to $50 \%$ of balanced rearrangements [2,9]. Of course, a fortuitous association between a balanced rearrangement and MCA/MR of another etiology cannot be excluded. In prenatal diagnosis, array CGH should be proposed to fetuses presented an apparently balanced de novo chromosomal rearrangement associated to malformations according to the literature [4].

\section{Acknowledgements:}

We thank the family members for their continued interest and cooperation. 
This works was partially supported with grants of the University Claude Bernard Lyon 1, faculté Lyon Nord and the Hospices Civils de Lyon.

We thank Dr Delphine Maucort-Boulch (Service de Biostatistiques, Hospices Civils de Lyon) for her help in statistical analyses.

We thank the DHOS (Direction de l'Hospitalisation et de l'Organisation des Soins) for their support in the development of several array CGH platforms in France. 


\section{WEB RESSOURCES}

Database of Genomic Variants: http://projects.tcag.ca/variation/

UCSC Genome Bioinformatics: http://genome.ucsc.edu/

Ensembl: http://www.ensembl.org/index.html

OMIM: http://www.ncbi.nlm.nih.gov/sites/entrez?db=omim

\section{REFERENCES}

[1] C. Astbury, L.A. Christ, D.J. Aughton, S.B. Cassidy, A. Kumar, E.E Eichler, S.

Schwartz, Detection of deletions in de novo "balanced" chromosome rearrangements: further evidence for their role in phenotypic abnormalities, Genet. Med. 6 (2004) 81-89.

[2] J. Baptista, C. Mercer, E. Prigmore, S.M. Gribble, N.P. Carter, V. Maloney, N.S. Thomas, P.A. Jacobs, J.A. Crolla, Breakpoint mapping and array CGH in translocations: comparison of a phenotypically normal and an abnormal cohort, Am. J. Hum. Genet. 82 (2008) 927-936.

[3] R. Ciccone, R. Giorda, G. Gregato, R. Guerrini, S. Giglio, R. Carrozzo, M.C. Bonaglia, E. Priolo, C. Laganà, R. Tenconi, M. Rocchi, T. Pramparo, O. Zuffardi, E. Rossi, Reciprocal translocations: a trap for cytogenetists?, Hum. Genet. 117 (2005) 571-582.

[4] M. De Gregori, R. Ciccone, P. Magini, T. Pramparo, S. Gimelli, J. Messa, F. Novara, A. Vetro, E. Rossi, P. Maraschio, M.C. Bonaglia, C. Anichini, G.B. Ferrero, M. Silengo, E. Fazzi, A. Zatterale, R. Fischetto, C. Previderé, S. Belli, A. Turci, G. Calabrese, F. Bernardi, E. Meneghelli, M. Riegel, M. Rocchi, S. Guerneri, F. Lalatta, L. Zelante, C. Romano, M. Fichera, T. Mattina, G. Arrigo, M. Zollino, S. Giglio, F. Lonardo, A. Bonfante, A. Ferlini, F. Cifuentes, H. Van Esch, L. Backx, A. Schinzel, J.R. Vermeesch, O. Zuffardi, Cryptic deletions are a common finding in "balanced" reciprocal and complex chromosome rearrangements: a study of 59 patients, J. Med. Genet. 44 (2007) 750-762.

[5] M. Della Monica, F. Lonardo, F. Faravelli, M. Pierluigi, D.V. Luquetti, M. De Gregori, O. Zuffardi, G. Scarano, A case of autism with an interstitial 1q deletion (1q23.324.2) and a de novo translocation of chromosomes 1q and 5q, Am. J. Med. Genet. A 143A (2007) 2733-2737.

[6] J.M. Dupont, L. Cuisset, M. Cartigny, D. Le Tessier, C. Vasseur, D. Rabineau, M. Jeanpierre, Familial reciprocal translocation $\mathrm{t}(7 ; 16)$ associated with maternal uniparental disomy 7 in a Silver-Russell patient, Am. J. Med. Genet. 111 (2002) 405-408.

[7] Y.S. Fan, P. Jayakar, H. Zhu, D. Barbouth, S. Sacharow, A. Morales, V. Carver, P. Benke, P. Mundy, L.J. Elsas, Detection of pathogenic gene copy number variations in patients with mental retardation by genomewide oligonucleotide array comparative genomic hybridization, Hum. Mutat. 28 (2007) 1124-1132. 
[8] J. Fantes, B. Redeker, M. Breen, S. Boyle, J. Brown, J. Fletcher, S. Jones, W. Bickmore, Y. Fukushima, M. Mannens, et al, Aniridia-associated cytogenetic rearrangements suggest that a position effect may cause the mutant phenotype, Hum. Mol. Genet. 4 (1995) 415-422.

[9] J.A. Fantes, E. Boland, J. Ramsay, D. Donnai, M. Splitt, J.A. Goodship, H. Stewart, M. Whiteford, P. Gautier, L. Harewood, S. Holloway, F. Sharkey, E. Maher, V. van Heyningen, J. Clayton-Smith, D.R. Fitzpatrick, G.C. Black, FISH mapping of de novo apparently balanced chromosome rearrangements identifies characteristics associated with phenotypic abnormality, Am. J. Hum. Genet. 82 (2008) 916-926.

[10] S.M. Gribble, E. Prigmore, D.C. Burford, K.M. Porter, B.L. Ng, E.J. Douglas, H. Fiegler, P. Carr, D. Kalaitzopoulos, S. Clegg, R. Sandstrom, I.K. Temple, S.A. Youings, N.S. Thomas, N.R. Dennis, P.A. Jacobs, J.A. Crolla, N.P. Carter, The complex nature of constitutional de novo apparently balanced translocations in patients presenting with abnormal phenotypes, J. Med. Genet. 42 (2005) 8-16.

[11] S. Hayashi, M. Ono, Y. Makita, I. Imoto, S. Mizutani, J. Inazawa, Fortuitous detection of a submicroscopic deletion at 1q25 in a girl with Cornelia-de Lange syndrome carrying $\mathrm{t}(5 ; 13)(\mathrm{p} 13.1 ; \mathrm{q} 12.1)$ by array-based comparative genomic hybridization, Am. J. Med. Genet. A 143A (2007) 1191-1197.

[12] A.W. Higgins, F.S. Alkuraya, A.F. Bosco, K.K. Brown, G.A. Bruns, D.J. Donovan, R. Eisenman, Y. Fan, C.G. Farra, H.L. Ferguson, J.F. Gusella, D.J. Harris, S.R. Herrick, C. Kelly, H.G. Kim, S. Kishikawa, B.R. Korf, S. Kulkarni, E. Lally, N.T. Leach, E. Lemyre, J. Lewis, A.H. Ligon, W. Lu, R.L. Maas, M.E. MacDonald, S.D. Moore, R.E. Peters, B.J. Quade, F. Quintero-Rivera, I. Saadi, Y. Shen, J. Shendure, R.E. Williamson, C.C. Morton, Characterization of apparently balanced chromosomal rearrangements from the developmental genome anatomy project, Am. J. Hum. Genet. 82 (2008) 712-722.

[13] V.M. Kalscheuer, J. Tao, A. Donnelly, G. Hollway, E. Schwinger, S. Kübart, C. Menzel, M. Hoeltzenbein, N. Tommerup, H. Eyre, M. Harbord, E. Haan, G.R. Sutherland, H.H. Ropers, J. Gécz, Disruption of the serine/threonine kinase 9 gene causes severe X-linked infantile spasms and mental retardation, Am. J. Hum. Genet. 72 (2003) 1401-1411.

[14] S. Kenwrick, M. Patterson, A. Speer, K. Fischbeck, K. Davies, Molecular analysis of the Duchenne muscular dystrophy region using pulsed field gel electrophoresis, Cell 48 (1987) 351-357.

[15] M. Kirchhoff, H. Rose, J. Maahr, T. Gerdes, M. Bugge, N. Tommerup, Z. Tümer, J. Lespinasse, P.K. Jensen, J. Wirth, C. Lundsteen, High resolution comparative genomic hybridisation analysis reveals imbalances in dyschromosomal patients with normal or apparently balanced conventional karyotypes, Eur. J. Hum. Genet. 8 (2000) 661-668.

[16] D.J. Kleinjan, V. van Heyningen, Position effect in human genetic disease, Hum. Mol. Genet. 7 (1998) 1611-1618.

[17] I. Krebs, I. Weis, M. Hudler, J.M. Rommens, H. Roth, S.W. Scherer, L.C. Tsui, E.M. Füchtbauer, K.H. Grzeschik, K. Tsuji, J. Kunz, Translocation breakpoint maps 5 kb 3' from 
TWIST in a patient affected with Saethre-Chotzen syndrome, Hum. Mol. Genet. 6 (1997) 1079-1086.

[18] A. Kumar, L.A. Becker, T.W. Depinet, J.M. Haren, C.L. Kurtz, N.H. Robin, S.B. Cassidy, D.J. Wolff, S. Schwartz, Molecular characterization and delineation of subtle deletions in de novo "balanced" chromosomal rearrangements, Hum. Genet. 103 (1998) 173178.

[19] C. Lee, A.J. Iafrate, A.R. Brothman, Copy number variations and clinical cytogenetic diagnosis of constitutional disorders, Nat. Genet. 39 (2007) S48-54.

[20] X.Y. Lu, M.T. Phung, C.A. Shaw, K. Pham, S.E. Neil, A. Patel, T. Sahoo, C.A. Bacino, P. Stankiewicz, S.H. Kang, S. Lalani, A.C. Chinault, J.R. Lupski, S.W. Cheung, A.L Beaudet, Genomic imbalances in neonates with birth defects: high detection rates by using chromosomal microarray analysis, Pediatrics 122 (2008) 1310-1318.

[21] K. Madan, A.W. Nieuwint, Y. van Bever, Recombination in a balanced complex translocation of a mother leading to a balanced reciprocal translocation in the child, Review of 60 cases of balanced complex translocations, Hum. Genet. 99 (1997) 806-815.

[22] B. Menten, N. Maas, B. Thienpont, K. Buysse, J. Vandesompele, C. Melotte, T. de Ravel, S. Van Vooren, I. Balikova, L. Backx, S. Janssens, A. De Paepe, B. De Moor, Y. Moreau, P. Marynen, J.P. Fryns, G. Mortier, K. Devriendt, F. Speleman, J.R. Vermeesch, Emerging patterns of cryptic chromosomal imbalance in patients with idiopathic mental retardation and multiple congenital anomalies: a new series of 140 patients and review of published reports, J. Med. Genet. 43 (2006) 625-633.

[23] P.C. Patsalis, P. Evangelidou, S. Charalambous, C. Sismani, Fluorescence in situ hybridization characterization of apparently balanced translocation reveals cryptic complex chromosomal rearrangements with unexpected level of complexity, Eur. J. Hum. Genet. 12 (2004) 647-653.

[24] A. Rauch, J. Hoyer, S. Guth, C. Zweier, C. Kraus, C. Becker, M. Zenker, U. Hüffmeier, C. Thiel, F. Rüschendorf, P. Nürnberg, A. Reis, U. Trautmann. Diagnostic yield of various genetic approaches in patients with unexplained developmental delay or mental retardation, Am J Med Genet A. 140 (2006) 2063-2074.

[25] S.P. Romana, M. Le Coniat, R. Berger, $\mathrm{t}(12 ; 21)$ : a new recurrent translocation in acute lymphoblastic leukemia, Genes Chromosomes Cancer 9 (1994) 186-191.

[26] C. Schluth-Bolard, M. Till, A. Labalme, C. Rey, E. Banquart, A. Fautrelle, T. MartinDenavit, M. Le Lorc'h, S.P. Romana, V. Lazar, P. Edery, D. Sanlaville, TWIST microdeletion identified by array CGH in a patient presenting Saethre-Chotzen phenotype and a complex rearrangement involving chromosomes 2 and 7, Eur. J. Med. Genet. 51 (2008) 156-164.

[27] L.G. Shaffer, B.A. Bejjani, B. Torchia, S. Kirkpatrick, J. Coppinger, B.C. Ballif, The identification of microdeletion syndromes and other chromosome abnormalities: cytogenetic methods of the past, new technologies for the future, Am J Med Genet C Semin Med Genet. $145 \mathrm{C}$ (2007) 335-345. 
[28] S. Solinas-Toldo, S. Lampel, S. Stilgenbauer, J. Nickolenko, A. Benner, H. Döhner, T. Cremer, P. Lichter, Matrix-based comparative genomic hybridization: biochips to screen for genomic imbalances, Genes Chromosomes Cancer 20 (1997) 399-407.

[29] P. Stankiewicz, A.L. Beaudet, Use of array CGH in the evaluation of dysmorphology, malformations, developmental delay, and idiopathic mental retardation, Curr. Opin. Genet.

Dev. 17 (2007) 182-192.

[30] C.D. van Karnebeek, M.C. Jansweijer, A.G. Leenders, M. Offringa, R.C. Hennekam, Diagnostic investigations in individuals with mental retardation: a systematic literature review of their usefulness, Eur. J. Hum. Genet. 13 (2005) 6-25.

[31] J.R. Vermeesch, H. Fiegler, N. de Leeuw, K. Szuhai, J. Schoumans, R. Ciccone, F. Speleman, A. Rauch, J. Clayton-Smith, C. Van Ravenswaaij, D. Sanlaville, P.C. Patsalis, H. Firth, K. Devriendt, O. Zuffardi, Guidelines for molecular karyotyping in constitutional genetic diagnosis, Eur. J. Hum. Genet. 15 (2007) 1105-1114.

[32] Warburton D: De novo balanced chromosome rearrangements and extra marker chromosomes identified at prenatal diagnosis: clinical significance and distribution of breakpoints. Am J Hum Genet 1991; 49: 995-1013. 


\section{Legends to Tables}

Table 1: Conventional karyotypes of the 47 patients

Table 2: Array CGH results in patients carrying an imbalance and corresponding phenotype

Table 3: Review of the literature and comparison with the present study 
Table 1: Conventional karyotypes of the 47 patients

\begin{tabular}{|c|c|c|c|c|}
\hline & Case & Karyotype & Inheritance & Array resolution \\
\hline & 1 & $46, \mathrm{XY}, \mathrm{t}(1 ; 18)(\mathrm{q} 11.1 ; \mathrm{q} 12.1)$ & $\mathrm{dn}$ & $244 \mathrm{~K}$ \\
\hline & 2 & $46, X X, t(1 ; 18)(p 36 ; q 21)$ & $\mathrm{dn}$ & $244 K$ \\
\hline & 3 & $46, \mathrm{XY}, \mathrm{t}(4 ; 22)(\mathrm{q} 21 ; \mathrm{q} 12)$ & $\mathrm{dn}$ & $244 \mathrm{~K}$ \\
\hline & 4 & $46, X Y, t(3 ; 5)(q 24 ; q 21)$ & pat & $44 \mathrm{~K}$ \\
\hline & 5 & $46, \mathrm{XX}, \mathrm{t}(10 ; 11)(\mathrm{p} 14 ; \mathrm{p} 15)$ & $\mathrm{dn}$ & $44 \mathrm{~K}$ \\
\hline & 6 & $46, \mathrm{XY}, \mathrm{t}(4 ; 11)(\mathrm{q} 27 ; \mathrm{q} 22 ; 3)$ & $\mathrm{dn}$ & $44 \mathrm{~K}$ \\
\hline & 7 & $46, \mathrm{XY}, \mathrm{t}(12 ; 14)(\mathrm{q} 21 ; \mathrm{q} 31)$ & $\mathrm{dn}$ & $44 \mathrm{~K}$ \\
\hline $\mathrm{T}$ & 8 & $46, X Y, t(7 ; 10)(q 3 ? 5 ; q 25 ?)$ & $\mathrm{dn}$ & $44 \mathrm{~K}$ \\
\hline $\mathrm{R}$ & 9 & $46, X Y, t(2 ; 6)(q 36 ; q 26)$ & pat & $44 \mathrm{~K}$ \\
\hline A & 10 & $46, X Y, t(2 ; 12)(p 16 ; q 14)$ & $\mathrm{dn}$ & $44 \mathrm{~K}$ \\
\hline $\mathrm{v}$ & 11 & $46, \mathrm{X}, \mathrm{t}(\mathrm{Y} ; 2)(\mathrm{q} 12 ; \mathrm{p} 24)$ & $\mathrm{dn}$ & $44 \mathrm{~K}$ \\
\hline & 12 & $46, X X, t(8 ; 18)(q 21 ; q 22)$ & $\mathrm{dn}$ & $44 \mathrm{~K}$ \\
\hline & 13 & $46, X X, t(5 ; 14)(q 34 ; q 31)$ & $\mathrm{dn}$ & $44 \mathrm{~K}$ \\
\hline o & 14 & $46, X X, t(4 ; 11)(q 3 ? 2 ; q 25)$ & $\mathrm{dn}$ & $44 \mathrm{~K}$ \\
\hline c & 15 & $46, \mathrm{XY}, \mathrm{t}(1 ; 4)(\mathrm{q} 43 ; \mathrm{q} 22)$ & mat & $44 \mathrm{~K}$ \\
\hline A & 16 & $46, \mathrm{XY}, \mathrm{t}(2 ; 9)(\mathrm{q} 37.2 ; \mathrm{p} 23)$ & pat & $44 \mathrm{~K}$ \\
\hline $\mathrm{T}$ & 17 & $46, X Y, t(2 ; 9)(q 32 ; q 13)$ & $\mathrm{dn}$ & $44 \mathrm{~K}$ \\
\hline & 18 & $46, X Y, t(5 ; 12)(q 34 ; q 23)$ & $\mathrm{dn}$ & $44 \mathrm{~K}$ \\
\hline 0 & 19 & $46, \mathrm{XY}, \mathrm{t}(7 ; 14)(\mathrm{p} 14 ; \mathrm{q} 21)$ & mat & $44 \mathrm{~K}$ \\
\hline $\mathrm{v}$ & 20 & $46, X X, t(2 ; 5)(p 22 ; q 12)$ & $\mathrm{dn}$ & $44 \mathrm{~K}$ \\
\hline & 21 & $46, \mathrm{XY}, \mathrm{t}(9 ; 12)(\mathrm{p} 23 ; \mathrm{q} 21)$ & $\mathrm{dn}$ & $44 \mathrm{~K}$ \\
\hline & 22 & $46, \mathrm{XX}, \mathrm{t}(2 ; 18)(\mathrm{p} 15 ; \mathrm{q} 21)$ & $\mathrm{dn}$ & $44 \mathrm{~K}$ \\
\hline & 23 & $46, \mathrm{XX}, \mathrm{t}(1 ; 18)(\mathrm{p} 31 ; \mathrm{q} 12.3)$ & mat & $44 \mathrm{~K}$ \\
\hline & 24 & $46, X X, t(1 ; 11)(q 12 ; q 13)$ & mat & $44 \mathrm{~K}$ \\
\hline & 25 & $46, X X, t(1 ; 14)(q 31 ; q 12)$ & $\mathrm{dn}$ & $44 \mathrm{~K}$ \\
\hline & 26 & $46, \mathrm{XY}, \mathrm{t}(2 ; 8)(\mathrm{q} 22 ; \mathrm{q} 24.2)$ & $\mathrm{dn}$ & $44 \mathrm{~K}$ \\
\hline & 27 & $46, \mathrm{XY}, \mathrm{t}(7 ; 12)(\mathrm{p} 11 ; \mathrm{p} 11)$ & $\mathrm{dn}$ & $44 \mathrm{~K}$ \\
\hline & 28 & $46, \mathrm{XY}, \mathrm{t}(1 ; 6)(\mathrm{q} 4 ? 1 ; \mathrm{q} 1 ? 4)$ & $\mathrm{dn}$ & $44 \mathrm{~K}$ \\
\hline & 29 & $46, X X, \operatorname{inv}(8)(p 22 q 12.2)$ & $\mathrm{dn}$ & $244 \mathrm{~K}$ \\
\hline & 30 & $46, X Y, \operatorname{inv}(11)(p 15 q 13)$ & mat & $244 \mathrm{~K}$ \\
\hline $\mathrm{N}$ & 31 & $46, X Y, \operatorname{inv}(4)(p 13 q 22)$ & pat & $244 \mathrm{~K}$ \\
\hline $\mathrm{V}$ & 32 & $46, X X, \operatorname{inv}(8)(q 21 q 24.2)$ & pat & $244 \mathrm{~K}$ \\
\hline $\mathrm{E}$ & 33 & $46, X X, \operatorname{inv}(1)(q 42 q 44)$ & $\mathrm{dn}$ & $44 \mathrm{~K}$ \\
\hline $\mathrm{R}$ & 34 & $46, X X, \operatorname{inv}(4)(p 16 q 32)$ & $\mathrm{dn}$ & $44 \mathrm{~K}$ \\
\hline S & 35 & $46, X X, \operatorname{inv}(13)(q 12.13 q 34)$ & $\mathrm{dn}$ & $44 \mathrm{~K}$ \\
\hline & 36 & $46, X Y, \operatorname{inv}(7)(p 13 q 21)$ & $\mathrm{dn}$ & $44 \mathrm{~K}$ \\
\hline $\mathrm{O}$ & 37 & $46, X Y, \operatorname{inv}(2)(p 13 q 13)$ & $\mathrm{dn}$ & $44 \mathrm{~K}$ \\
\hline $\mathrm{N}$ & 38 & $46, X, \operatorname{inv}(X)(p 21.1 q 21.1)$ & $\mathrm{dn}$ & $44 \mathrm{~K}$ \\
\hline & 39 & $46, X Y, \operatorname{inv}(7)(p 14 q 21.1)$ & mat & $44 \mathrm{~K}$ \\
\hline & 40 & $46, X X, \operatorname{inv}(1)(p 21 q 13)$ & mat & $44 \mathrm{~K}$ \\
\hline & 41 & $46, X Y, t(1 ; 7 ; 11)(p 35 ; q 33 ; q 12)$ & $\mathrm{dn}$ & $244 \mathrm{~K}$ \\
\hline & 42 & $46, X X, t(2 ; 3 ; 6)(q 21 ; q 22 ; p 26.1)$ & $\mathrm{dn}$ & $244 \mathrm{~K}$ \\
\hline & 43 & $46, \mathrm{XY}, \mathrm{t}(2 ; 7)(\mathrm{p} 24 ; \mathrm{p} 21), \operatorname{ins}(7)(\mathrm{p} 21.3 \mathrm{q} 21.3 \mathrm{q} 22)$ & $\mathrm{dn}$ & $44 \mathrm{~K}$ \\
\hline & 44 & $46, X Y, \operatorname{inv}(5)(p 14 q 23) t(1 ; \operatorname{inv}(5))(p 21 ; q 23)$ & pat & $44 \mathrm{~K}$ \\
\hline C & 45 & $46, X X, \operatorname{ins}(7 ; 4)(q 31 ; q 27 q 32)$ & mat & $44 \mathrm{~K}$ \\
\hline $\begin{array}{l}C \\
R\end{array}$ & 46 & $\begin{array}{l}46, X X, t(2 ; 5 ; 10)(2 p t e r \rightarrow 2 q 22:: 2 q 34 \rightarrow 2 q t e r ; \\
5 p t e r \rightarrow 5 q 21:: 2 q 22 \rightarrow 2 q 33:: 10 p 14 \rightarrow 10 p t e r ; 10 q t e r \\
\rightarrow 10 \mathrm{o} 14:: 2 \mathrm{q} 33 \rightarrow 2 \mathrm{a} 34:: 5 \mathrm{a} 21 \rightarrow 5 \mathrm{ater}) \\
\end{array}$ & dn & $44 \mathrm{~K}$ \\
\hline
\end{tabular}




\begin{tabular}{|c|l|c|c|}
\hline 47 & $\begin{array}{l}46, \mathrm{XX}, \mathrm{t}(1 ; 2 ; 9)(1 \mathrm{pter} \rightarrow 1 \mathrm{q} 31:: 9 \mathrm{p} 12 \rightarrow 9 \mathrm{pter} ; \\
2 \mathrm{pter} \rightarrow 2 \mathrm{q} 24:: 1 \mathrm{q} 41 \rightarrow 1 \mathrm{qter} ; 9 \mathrm{qter} \rightarrow 9 \mathrm{p} 12: \\
1 \mathrm{a} 31 \rightarrow 1 \mathrm{a} 41:: 2 \mathrm{q} 24 \rightarrow 2 \mathrm{ater}) \mathrm{t}(11: 14)(\mathrm{a} 11: \mathrm{a} 23)\end{array}$ & dn & $44 \mathrm{~K}$ \\
\hline
\end{tabular}

dn: de novo ; pat: paternal; mat: maternal 
Table 2: Array CGH results in patients carrying an imbalance and corresponding phenotype

a) de novo rearrangement group

\begin{tabular}{|c|c|c|c|c|c|}
\hline Case & Karyotype & Rearranged region & Inheritance & Size Mb & Phenotype \\
\hline $1^{*}$ & $46, X Y, t(1 ; 18)(q 11.1 ; q 12.1)$ & $\operatorname{del}(14)(q 32.2 q 32.2)$ & dn & 0.06 & $\begin{array}{l}\text { Moderate mental retardation, macrosomia, leukodystrophy, } \\
\text { hexadactyly }\end{array}$ \\
\hline 3 & $46, \mathrm{XY}, \mathrm{t}(4 ; 22)(\mathrm{q} 21 ; \mathrm{q} 12)$ & $\operatorname{del}(4)(q 21.22 q 21.22)$ & $\mathrm{dn}$ & 0.77 & Moderate mental retardation, facial dysmorphism \\
\hline 8 & $46, X Y, t(7 ; 10)(q 3 ? 5 ; q 25 ?)$ & $\operatorname{del}(7)(q 35 q 36.1)$ & $\mathrm{dn}$ & 5.13 & $\begin{array}{l}\text { Severe mental retardation, autistic troubles, seizures, facial } \\
\text { dysmorphism }\end{array}$ \\
\hline 17 & $46, X Y, t(2 ; 9)(q 32 ; q 13)$ & $\operatorname{del}(9)(q 21.13 q 21.31)$ & dn & 6.49 & Mild mental retardation, speech delay, facial dysmorphism, hirsutism \\
\hline 21 & $46, X Y, t(9 ; 12)(p 23 ; q 21)$ & del(9)(p24.2p23) & $\mathrm{dn}$ & 11.61 & $\begin{array}{l}\text { Severe mental retardation, speech delay, aggressivity, muscular } \\
\text { hypotonia, hydronephrosis, cryptorchidism, diabetes }\end{array}$ \\
\hline $22^{*}$ & $46, X X, t(2 ; 18)(p 15 ; q 21)$ & del(2)(p21p21) & $\mathrm{dn}$ & 0.30 & $\begin{array}{l}\text { Mental retardation, speech delay, hyperactivity, facial dysmorphism, } \\
\text { cleft lip and palate, congenital cardiac defect, syndactyly }\end{array}$ \\
\hline 25 & $46, X X, t(1 ; 14)(q 31 ; q 12)$ & del(1)(q25.2q31.2) & $\mathrm{dn}$ & 15.37 & $\begin{array}{l}\text { Moderate mental retardation, hypotonia, growth retardation, facial } \\
\text { dysmorphism, trigonocephaly }\end{array}$ \\
\hline $27^{\star}$ & $46, X Y, t(7 ; 12)(p 11 ; p 11)$ & del(2)(q33.1q33.1) & $\mathrm{dn}$ & 2.02 & $\begin{array}{l}\text { Severe mental retardation, autistic troubles, growth retardation, facial } \\
\text { dysmorphism, microcephaly, dental anomalies }\end{array}$ \\
\hline $29^{*}$ & $46, X X, \operatorname{inv}(8)(p 22 q 12.2)$ & $\operatorname{del}(1)(\mathrm{q} 24.1 \mathrm{q} 24.2)$ & $\mathrm{dn}$ & 8.87 & $\begin{array}{l}\text { Mild mental retardation, seizures, growth retardation, facial } \\
\text { dysmorphism }\end{array}$ \\
\hline $34^{*}$ & $46, X X, \operatorname{inv}(4)(p 16 q 32)$ & $\operatorname{del}(13)(q 12.3 q 13.1)$ & $\mathrm{dn}$ & 3.52 & $\begin{array}{l}\text { Moderate mental retardation, speech delay, obesity, facial } \\
\text { dysmorphism, camptodactyly }\end{array}$ \\
\hline 35 & $46, X X, \operatorname{inv}(13)(q 12.13 q 34)$ & $\operatorname{del}(13)(q 12.3 q 13.1)$ & $\mathrm{dn}$ & 3.85 & $\begin{array}{l}\text { Severe mental retardation, microcephaly, muscular hypertonia, } \\
\text { growth retardation, liver steatosis }\end{array}$ \\
\hline $36^{*}$ & $46, X Y, \operatorname{inv}(7)(p 13 q 21)$ & $\operatorname{del}(14)(q 22.1 q 22.1)$ & dn & 1.06 & Mild mental retardation, spasticity, poor motor coordination \\
\hline $42^{*}$ & $46, \mathrm{XX}, \mathrm{t}(2 ; 3 ; 6)(\mathrm{q} 21 ; \mathrm{q} 22 ; \mathrm{p} 26.1)$ & $\begin{array}{l}\operatorname{del}(2) q 34 q 34) \\
\operatorname{del}(6 q 25.1 q 25.2)\end{array}$ & $\begin{array}{l}\mathrm{dn} \\
\mathrm{dn}\end{array}$ & $\begin{array}{l}4.3 \\
4.9\end{array}$ & $\begin{array}{l}\text { Moderate mental retardation, seizures, facial dysmorphism, fingers } \\
\text { hyperlaxity }\end{array}$ \\
\hline 43 & $46, \mathrm{XY}, \mathrm{t}(2 ; 7)(\mathrm{p} 24 ; \mathrm{p} 21), \operatorname{ins}(7)(\mathrm{p} 21.3 \mathrm{q} 21.3 \mathrm{q} 22)$ & $\operatorname{del}(7)(p 21.3 p 21.3)$ & $\mathrm{dn}$ & 0.69 & $\begin{array}{l}\text { Mild mental retardation, craniosynostosis, syndactyly (Saethre- } \\
\text { Chotzen syndrome), cryptorchidism, kidney hypoplasia }\end{array}$ \\
\hline 46 & $46, X X, t(2 ; 5 ; 10)$ & $\operatorname{del}(2)(q 33.3 q 33.3)$ & $\mathrm{dn}$ & 3.64 & $\begin{array}{l}\text { Facial dysmorphism, congenital cardiac defect, brain malforamtion, } \\
\text { hepatosplenomegaly, cryptorchidism }\end{array}$ \\
\hline 47 & $46, \mathrm{XX}, \mathrm{t}(1 ; 2 ; 9), \mathrm{t}(11 ; 14)(\mathrm{q} 11 ; \mathrm{q} 23)$ & $\operatorname{del}(1)(q 23.3 q 24.2)$ & $\mathrm{dn}$ & 3.57 & $\begin{array}{l}\text { Mental retardation, muscular hypotonia, growth retardation, facial } \\
\text { dysmorphism, corpus callosum hypoplasia, renal hypoplasia, anal } \\
\text { anteposition, sacrococcygeal dimple }\end{array}$ \\
\hline
\end{tabular}

b) inherited rearrangement group

\begin{tabular}{|c|l|l|c|c|l|}
\hline Case & \multicolumn{1}{|c|}{ Karyotype } & Rearranged region & Inheritance & Size Mb & \multicolumn{1}{|c|}{ Phenotype } \\
\hline $9^{*}$ & $46, \mathrm{XY}, \mathrm{t}(2 ; 6)(\mathrm{q} 36 ; \mathrm{q} 26)$ pat & del(6)(q24.2q24.3) & $\mathrm{pat}$ & 1.21 & Autistic troubles \\
\hline \hline $31^{*}$ & $46, \mathrm{XY}, \operatorname{inv}(4)(\mathrm{p} 13 \mathrm{q} 22) \mathrm{pat}$ & del(15)(q21.3q21.3) & $\mathrm{pat}$ & 0.08 & $\begin{array}{l}\text { Mild mental retardation, seizures, growth retardation, facial } \\
\text { dysmophism, brachymesophalangia }\end{array}$ \\
\hline 40 & $46, \mathrm{XX}, \operatorname{inv}(1)(\mathrm{p} 21 \mathrm{q} 13) \mathrm{mat}$ & $\operatorname{del}(1)(\mathrm{p} 21.2 \mathrm{p} 21.2)$ & $\mathrm{dn}$ & 1.23 & Severe mental retardation, microcephaly, facial dysmorphism \\
\hline \hline 45 & $46, \mathrm{XX}, \operatorname{ins}(7 ; 4)(\mathrm{q} 31 ; \mathrm{q} 27 \mathrm{q} 32) m a t$ & del(4)(q31.3q32.1) & $\mathrm{dn}$ & 4.03 & Moderate mental retardation, seizures, scoliosis \\
\hline
\end{tabular}

Transloc: translocation; Inv: inversion: CCR: complex chromosomal rearrangement; dn: de novo; pat: paternal; mat: maternal; Mb: megabases Patients carrying a deletion unrelated to the balanced rearrangement breakpoint are marked by an asterix. 
Table 3: Review of the litterature and comparison with the present study

\begin{tabular}{|l|ccccc|}
\hline \multirow{2}{*}{ Array } & Gribble et al.[10] & De Gregori et al.[4] & Baptista et al.[2] & Present study \\
\cline { 2 - 5 } Resolution & BAC/PAC & Oligonucleotides & BAC/PAC & Oligonucleotides \\
Rearrangements & 3,500 clones & $44 \mathrm{~K} / 244 \mathrm{~K}$ & 30,000 clones & $44 \mathrm{~K} / 244 \mathrm{~K}$ \\
de novo /inherited & $\mathrm{t} / \mathrm{CCR}$ & $\mathrm{t} / \mathrm{CCR}$ & $\mathrm{t}$ & $\mathrm{t} /$ inv/CCR \\
Number of patients & de novo & de novo & de novo & de novo & inherited \\
Rate imbalance & 10 & 59 & 14 & 33 & 14 \\
Imbalance size $(\mathrm{Mb})$ & $2.2-6.2$ & $45.7 \%(24 / 59)$ & $28.6 \%(4 / 14)$ & $48.5 \%(16 / 33)$ & $28.6 \%(4 / 14)$ \\
Imbalance at distance & $60 \%(3 / 5)$ & $41.6 \%(10 / 24)$ & $25 \%(1 / 4)$ & $56.2 \%(9 / 16)$ & $50 \%(2 / 4)$ \\
from breakpoint & & & & & $0.06-14-8.4$ \\
\hline
\end{tabular}

t: translocation; CCR: complex chromosomal rearrangement; inv: inversion 